\title{
Transport pathways of microphytobenthos- originating organic carbon in the food web of an exposed hard bottom shore in the Seto Inland Sea, Japan
}

\author{
Noriyuki Takai ${ }^{1, *}$, Akemi Yorozu ${ }^{2}$, Terumi Tanimoto ${ }^{3}$, Akira Hoshika $^{3}$, \\ Kiyoshi Yoshihara ${ }^{4}$
}

\begin{abstract}
${ }^{1}$ Shimoda Marine Biological Station, College of Bioresource Sciences, Nihon University, Shimoda 415-0014, Japan
${ }^{2}$ Graduate School of Biosphere Science, Hiroshima University, Higashi-Hiroshima 739-8528, Japan

${ }^{3}$ National Institute of Advanced Industrial Science and Technology (AIST), Kure 737-0197, Japan

${ }^{4}$ Department of Marine Science and Resources, College of Bioresource Sciences, Nihon University, Fujisawa 252-8510, Japan
\end{abstract}

\begin{abstract}
Benthic microalgal production has been clarified to be comparable to water column production in coastal shallow water ecosystems. The present study examined carbon transport pathways from microphytobenthos to predators in a food web of an exposed hard bottom shore in the Seto Inland Sea of Japan in winter, noting the intermediary role of suspension feeders in the carbon transport. Natural abundances of carbon and nitrogen stable isotopes were examined for epilithic organic matter (EOM), suspended particulate organic matter (SPOM), a macroalga, molluscs, crustaceans and fish. All the heterotrophs, including herbivores, suspension feeders and carnivores, showed high $\delta^{13} \mathrm{C}$ signatures of -15.5 to $-9.7 \%$, relative to the $\delta^{13} \mathrm{C}$ of -20.7 to $-19.7 \%$ for the SPOM collected from the offshore surface water as an indicator of phytoplankton. At the shoreline point, the SPOM showed high $\delta^{13} \mathrm{C}$ values of -16.0 to $-13.0 \%$, overlapping with the values of -15.4 to $-12.6 \%$ for the EOM indicative of microphytobenthos collected at the low sea level points, and abundantly included microalgae of the same species found in the epilithic matter. It was thus considered that resuspension of ${ }^{13} \mathrm{C}$-enriched microphytobenthos increased the $\delta^{13} \mathrm{C}$ of SPOM in the surf zone and consequently increased the $\delta^{13} \mathrm{C}$ of the suspension feeders through their feeding on the suspended matter. The $\delta^{15} \mathrm{~N}$ of carnivores, which overlapped in $\delta^{13} \mathrm{C}$ with these primary consumers, markedly increased with the trophic position. These results indicate that, not only grazing, but also suspension feeding functioned as transport pathways of the ${ }^{13} \mathrm{C}$-enriched microphytobenthos in the food web.
\end{abstract}

KEY WORDS: Microphytobenthos $\cdot$ Carbon source $\cdot$ Shore $\cdot$ Food web $\cdot \delta^{13} \mathrm{C} \cdot \delta^{15} \mathrm{~N}$

Resale or republication not permitted without written consent of the publisher

\section{INTRODUCTION}

The microphytobenthos provides a large amount of organic carbon to coastal shallow water ecosystems (MacIntyre et al. 1996). The estimates of its annual primary production from intertidal sediments in estuaries range from 29 to $314 \mathrm{~g} \mathrm{C} \mathrm{m}^{-2}$, comparable to the production estimates for estuarine phytoplankton, ranging from 7 to $875 \mathrm{~g} \mathrm{C} \mathrm{m}^{-2}$ (Underwood \& Kromkamp 1999).
This benthic microalgal production is generally considered to vary with shore type. The microalgal film on a hard surface can be extremely productive on rocky shores, in contrast with sediment shores or exposed sandy beaches, where phytoplankton produced in situ or imported are a comparatively more important input of energy into the ecosystem (Raffaelli \& Hawkins 1999). It is also supposed that this microalgal film on the hard surface can be more productive than macro- 
algae on more exposed rocky shores (Raffaelli \& Hawkins 1999).

Our concern here is what kind of primary consumers play intermediary roles in the transport of organic carbon from the microphytobenthos to top predators in shore ecosystems. de Jonge \& van Beusekom (1992) suggested that half of the food of benthic suspension feeders in an estuary consisted of resuspended microphytobenthos, based on the proportion of microphytobenthos in the suspended matter. Kamermans (1994) found that percentages of benthic algal cells included in stomachs of both suspension- and deposit-feeding bivalves in a tidal flat showed significant positive correlations with the cell percentages in the bottom layer water, but low correlations with the cell percentages at the sediment surface. This would mean that these bivalves consumed the microphytobenthos via resuspension of the microphytobenthos. On the other hand, the results of stable isotope tracer-addition experiments and analyses of natural isotope abundances indicated that the food source of primary consumers in a tidal flat was planktonic algae for the suspension feeders and microphytobenthos for the deposit feeders (Herman et al. 2000, Middelburg et al. 2000). It is likely that the kinds of intermediate players differ among different ecosystems.

Recently, Takai et al. (2002) indicated that fish, small benthic crustaceans and Japanese oysters Crassostrea gigas inhabiting an island shore in the western Seto Inland Sea of Japan were mainly dependent on carbon from benthic primary production, on the basis of the carbon and nitrogen stable isotope signatures. However, this investigation did not clarify the kinds of benthic plants contributing to these littoral consumers nor the process of carbon transfer from the plants to primary consumers. In the present study, we examined the stable isotope distributions of the organisms inhabiting this shore site to demonstrate the carbon supply from microphytobenthos to heterotrophs and elucidate the transport pathways of the microphytobenthosoriginating carbon in the food web.

Carbon and nitrogen stable isotope ratios of an animal have been increasingly used to obtain time-integrated information on its feeding habits and on the organic carbon transport through aquatic food webs (Wada et al. 1987, Fry 1988). The $\delta^{13} \mathrm{C}$ value shows a slight enrichment of $1 \%$ or less for an animal during a single feeding process (DeNiro \& Epstein 1978, Rau et al. 1983). This conservative nature of $\delta^{13} \mathrm{C}$ along a food chain can provide information on the carbon sources of high trophic consumers in aquatic food webs. On the other hand, ${ }^{15} \mathrm{~N}$ exhibits stepwise enrichment of 3 to $4 \%$ from prey to predator (DeNiro \& Epstein 1981, Minagawa \& Wada 1984). Interpretation of consumers $\delta^{15} \mathrm{~N}$ relative to an appropriate baseline $\delta^{15} \mathrm{~N}$ value provides a quantitative measure of their trophic position. The $\delta^{13} \mathrm{C}-\delta^{15} \mathrm{~N}$ map in an ecosystem can thus show a schematic food web structure on a corresponding food base.

The $\delta^{13} \mathrm{C}$ of marine primary producers is mainly distributed from -27 to $-8 \%$ for macroalgae, from -15 to $-3 \%$ for seagrasses, from $-20 \%$ to $-10 \%$ for microphytobenthos and from -24 to $-18 \%$ for phytoplankton in temperate regions (Fry \& Sherr 1984). Specifically, the average of $\delta^{13} \mathrm{C}$ data from the literature was reported to be $5 \%$ higher in benthic algae than in phytoplankton (France 1995). These general $\delta^{13} \mathrm{C}$ distributions of the primary producers apply to the distributions in Hiroshima Bay as well: the $\delta^{13} \mathrm{C}$ mainly ranged from -23 to $-11 \%$ for macroalgae, from -17 to $-13 \%$ for epilithic organic matter ( 0.7 to $125 \mu \mathrm{m}$ ) (an indicator of epilithic microalgae) and from -23 to $-19 \%$ for particulate organic matter (0.7 to $125 \mu \mathrm{m}$ ) (an indicator of phytoplankton) in the offshore surface (Takai et al. 2001, 2002). Based on these $\delta^{13} \mathrm{C}$ distributions of the primary producers, we identified the carbon sources of the heterotrophs in the exposed hard bottom shore ecosystem of an uninhabited and undeveloped island in the western Seto Inland Sea in winter.

\section{MATERIALS AND METHODS}

Sampling. Hiroshima Bay is located in the western area of the Seto Inland Sea of Japan, with an area of about $1000 \mathrm{~km}^{2}$ and an average depth of $24 \mathrm{~m}$ (Fig. 1a). The standing stock of chlorophyll $a(\mathrm{chl} a)$ in the surface layer ( 0 to $10 \mathrm{~m}$ ) of the water column has been reported to be $47.4 \mathrm{mg} \mathrm{m}^{-2}$ in the bay, remarkably higher than the average $\left(25.7 \mathrm{mg} \mathrm{m}^{-2}\right)$ of the overall area of the Seto Inland Sea (Tada et al. 1998). The chl a standing stock of the microphytobenthos has scarcely been investigated in the Seto Inland Sea, but Ono et al. (1999) recently found a high chl a concentration of 32.5 to $193 \mathrm{mg} \mathrm{m}^{-2}$ for the surface sediment of Hiroshima Bay in October and January. With regard to macrophytes, Anonymous (1994) has reported that seaweed beds exist in an area of 2059 ha along the Hiroshima district, but the standing stock of photosynthesis pigments and the carbon budget have not precisely been evaluated.

We collected epilithic organic matter (EOM), suspended particulate organic matter (SPOM) and shore animals at low tides from Koguro-Kamijima Island (Fig. 1). This island is uninhabited and undeveloped, with shores mostly consisting of rock and sand. All samples were collected on 22 December 2000, except for the molluscs and barnacles Pollicipes mitella, which were collected on 22 February 2000.

The EOM was collected at 4 sea-level points (Pts. A, B, C and D) at this shore site (Fig. 1b). We brushed the 


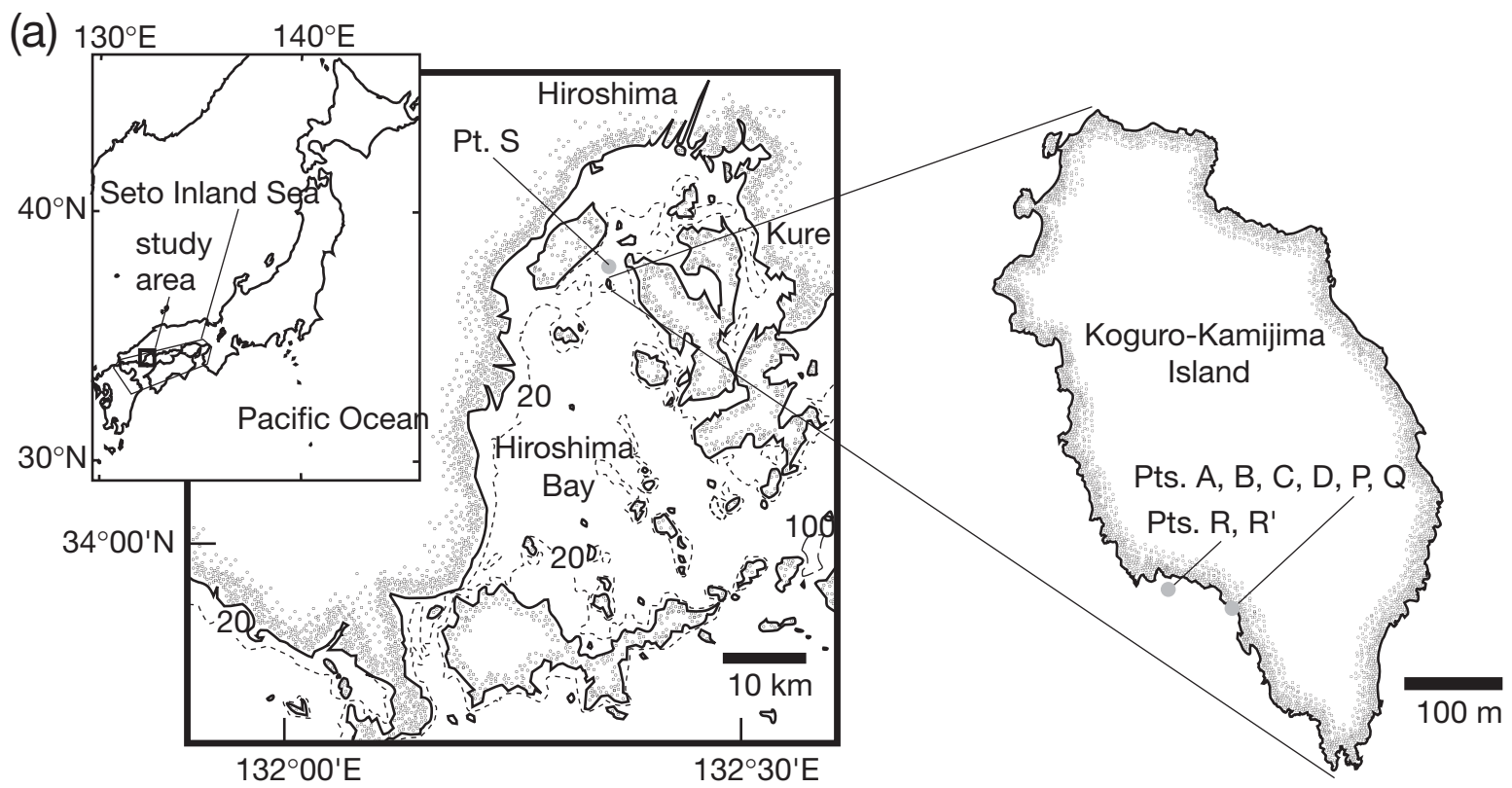

(b)
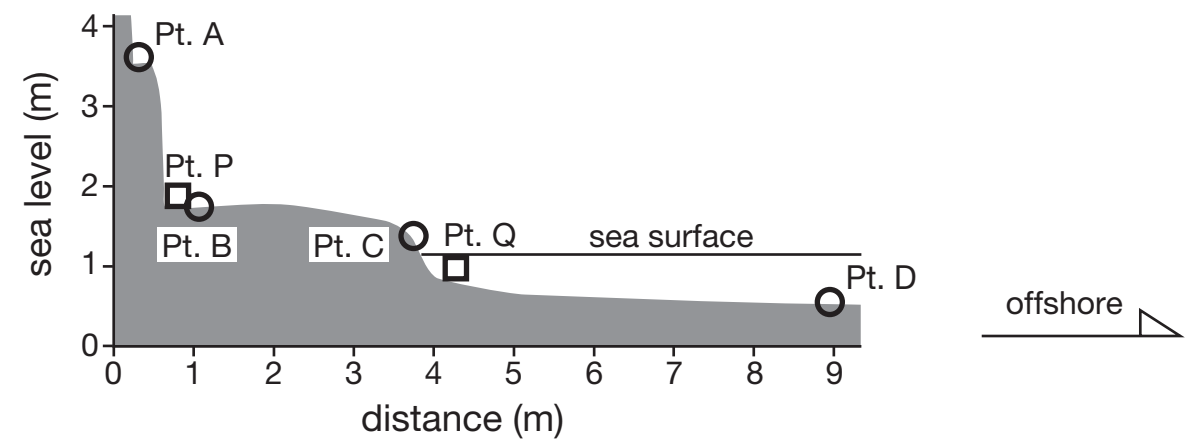

Fig. 1. Study area. (a) Koguro-Kamijima Island. Isobaths are shown with short dashed lines for $20 \mathrm{~m}$ and long dashed lines for $100 \mathrm{~m}$. (b) Transect of the shore site where the suspended particulate organic matter (Pts. P and Q; open squares) and the epilithic organic matter (Pts. A, B, C and D; open circles) were collected

surfaces of rocks at Pts. A, B and C and the surfaces of submerged stones at Pt. D. This brush was churned in seawater, which had been filtrated through precombusted $\left(450^{\circ} \mathrm{C}, 2 \mathrm{~h}\right) \mathrm{GF} / \mathrm{F}$ filters in advance, in order to wash the EOM off into the seawater. A part of this cloudy water was fixed with glutaraldehyde $(5 \%)$ for microscopic observation of the microalgae included in the EOM after it was sieved through a $125 \mu \mathrm{m}$ mesh sieve. The other portion of the cloudy water was washed through 125, 63, 32 and $15 \mu \mathrm{m}$ mesh sieves, in order to collect EOM in the size ranges of 63 to $125 \mu \mathrm{m}$, 32 to $63 \mu \mathrm{m}$ and 15 to $32 \mu \mathrm{m}$. The water filtered through a $15 \mu \mathrm{m}$ mesh sieve was further passed through precombusted GF/F filters, in order to collect particles of 0.7 to $15 \mu \mathrm{m}$. We collected 1 sample for each combination of sampling points and particle-size fractions.

The SPOM was collected from seawater samples that were drawn from a tide pool point $(\mathrm{P})$, a shoreline point
(Q), the surface of a $2 \mathrm{~m}$ depth point (R), the bottom of a $2 \mathrm{~m}$ depth point (R') and an offshore surface point (S) (Fig. 1). The water was drawn with a Van-Dorn water sampler from Pt. R' and with a bucket from the other points. A part of the water (2 l) was fixed with glutaraldehyde $(5 \%)$ for microscopic observation of the microalgae included in the SPOM after it was sieved through a $125 \mu \mathrm{m}$ mesh sieve. The SPOM particles in the size ranges of 63 to $125 \mu \mathrm{m}, 32$ to $63 \mu \mathrm{m}, 15$ to $32 \mu \mathrm{m}$ and 0.7 to $15 \mu \mathrm{m}$ were collected in the same way as the EOM particles. The SPOM in the surface water collected at Pts. R and $\mathrm{S}$ were separated into 15 to $125 \mu \mathrm{m}$ and 0.7 to $15 \mu \mathrm{m}$ particles, since the particles were not abundantly included in the surface water and thus the particles of the 15 to $125 \mu \mathrm{m}$ fraction could not be separated into 3 more detailed size fractions. We collected 1 sample for each combination of sampling points and particle-size fractions. 
Small benthic crustaceans were collected from the surfaces of the stones, macroalgae and the shells of bivalves in littoral and sublittoral zones at the shore site. In particular, the crustaceans collected in the sublittoral zone were the epiphyton inhabiting the surfaces of Sargassum macroalgae. Molluscs and barnacles were collected from the surfaces of rock mass in the littoral zone. Fish were captured with a throw net in the sublittoral zone.

Stable isotope analyses. The samples were stored at $-20^{\circ} \mathrm{C}$. The isotope ratios of the crustaceans were analyzed for mixed individuals (the whole body) in amphipods and decapods and for adductor muscles in barnacles. Muscles of the fish were excised from the trunk behind a pectoral fin. Tissues that were analyzed for the molluscs differed with the species, since there are interspecific differences for the quantity of the muscles that can be collected from feet and adductor muscles. Feet were excised from chitons Liolophura japonica and gastropods, except centipede shells Serpulorbis imbricatus, for analyses. The whole soft tissue was examined for $S$. imbricatus, since we could not identify the kinds of tissues in the anatomical process. The adductor muscles of bivalves were analyzed. The feet of the gastropods lipped periwinkles Monodonta labio and turban shells Lunella coronata coreensis were analyzed after being mixed with the feet of other individuals of the same kind. Yorozu (2000) confirmed that the stable isotope ratios of bivalves collected in summer were not significantly different between feet and adductor muscles, thus justifying the use of data from these 2 muscle tissues. The leaf of the macroalga Sargassum horneri, to which the small crustaceans in the sublittoral zone attached, was also analyzed.

These tissues were dried at $60^{\circ} \mathrm{C}$ and ground to a fine powder. The animal tissues were defatted with a chloroform:methanol (2:1) solution. The EOM and SPOM were exposed to the vapor of concentrated $\mathrm{HCl}$ for a day in order to eliminate carbonates and were subsequently dried in a vacuum desiccator. Stable isotope ratios of carbon and nitrogen were measured with a MAT 252 mass spectrometer (Finnigan MAT) coupled with an elemental analyzer (Carlo Erba). Isotope ratios, $\delta^{13} \mathrm{C}$ and $\delta^{15} \mathrm{~N}$, are expressed as per mil deviations from the standard as defined by the following equation:

$$
\delta^{13} \mathrm{C}, \delta^{15} \mathrm{~N}=\left[R_{\text {sample }} / R_{\text {standard }}-1\right] \times 1000(\%)
$$

where $R={ }^{13} \mathrm{C} /{ }^{12} \mathrm{C}$ or ${ }^{15} \mathrm{~N} /{ }^{14} \mathrm{~N}$. Belemnite (PDB) and atmospheric nitrogen were used as the isotope standards for carbon and nitrogen, respectively. The analytical precision for the isotopic analyses was $\pm 0.28 \%$ for both $\delta^{13} \mathrm{C}$ and $\delta^{15} \mathrm{~N}$.

Statistical analyses. We performed Friedman's test for the EOM and SPOM and the Kruskal-Wallis test for the molluscs in the statistical analyses of isotopic values. The statistical analyses for the crustaceans could not be performed, because the decapods and barnacles were short of the number of samples analyzed for stable isotope ratios. The statistical analyses for the SPOM were performed among the samples collected at Pts. P, Q and R'; the data of the samples at Pts. R and $\mathrm{S}$ were excluded from the statistical analyses, since the SPOM collected at Pts. R and S could not be separated into 4 size fractions. In the Kruskal-Wallis test for the molluscs, the species whose isotope ratios were analyzed for only 1 sample were excluded from the statistical analyses.

Calculation of the test statistic $\left(\chi_{\mathrm{r}}^{2}\right.$ for the Friedman's test and $H$ for the Kruskal-Wallis test) and determination of critical values for the statistic were performed according to Ichihara (1990). We also referred to Zar (1996) for the correction of the test statistic concerning tied ranks. The number of the groups compared (a) and the sampling blocks $(b)$ was described for the Friedman's test.

\section{RESULTS}

\section{Stable isotope ratios of EOM and SPOM}

The stable isotope ratios of the EOM ranged from $-18.1 \%$ (Pt. A, 63 to $125 \mu \mathrm{m}$ ) to $-12.6 \%$ (Pt. D, 63 to 125 $\mu \mathrm{m}$ ) for $\delta^{13} \mathrm{C}$ and from $3.8 \%$ (Pt. A, 63 to $125 \mu \mathrm{m}$ ) to $9.8 \%$ (Pt. D, 15 to $32 \mu \mathrm{m}$ ) for $\delta^{15} \mathrm{~N}$ (Figs. $2 \& 3$ ). The $\delta^{15} \mathrm{~N}$ of the EOM increased toward lower sea-level points (Friedman's test, $\chi_{\mathrm{r}}^{2}=12.0, a=4, b=4, \mathrm{p}<0.01$ ), while such a significant location-related isotopic change was not found for $\delta^{13} \mathrm{C}$ (Friedman's test, $\chi_{\mathrm{r}}^{2}=3.9, a=4, b=$ 4). Significant difference for the $\delta^{15} \mathrm{~N}$ was also found among the size fractions of the EOM (Friedman's test, $\left.\chi_{\mathrm{r}}^{2}=11.1, a=4, b=4, \mathrm{p}<0.01\right)$; the $\delta^{15} \mathrm{~N}$ of the EOM was significantly higher in smaller size groups. On the other hand, no significant particle size-related isotopic change was found for $\delta^{13} \mathrm{C}$ (Friedman's test, $\chi_{\mathrm{r}}^{2}=0, a=$ $4, b=4)$. The $\delta^{13} \mathrm{C}$ values were higher in smaller size fractions at the higher sea-level points (A and B) and higher in larger fractions at the lower sea-level points (C and D).

The stable isotope ratios of the SPOM ranged from $-20.7 \%$ (Pt. S, 0.7 to $15 \mu \mathrm{m}$ ) to $-13.0 \%$ (Pt. Q, 32 to $63 \mu \mathrm{m}$ and 63 to $125 \mu \mathrm{m}$ ) for $\delta^{13} \mathrm{C}$ and from $6.6 \%$ (Pt. R, 0.7 to $15 \mu \mathrm{m}$ ) to $9.8 \%$ (Pt. P, 0.7 to $15 \mu \mathrm{m}$ ) for $\delta^{15} \mathrm{~N}$ (Figs. $2 \& 3$ ). The $\delta^{13} \mathrm{C}$ of the SPOM varied with the location. The $\delta^{13} \mathrm{C}$ at the offshore surface point (S) showed the lowest values of -20.7 to $-19.7 \%$, while the $\delta^{13} \mathrm{C}$ at the shoreline point $(\mathrm{Q})$ was the highest $(-16.0$ to $-13.0 \%$ ). There was a significant location-related difference among 3 points ( $\mathrm{P}, \mathrm{Q}$ and $\mathrm{R}^{\prime}$ ) (Friedman's test, 

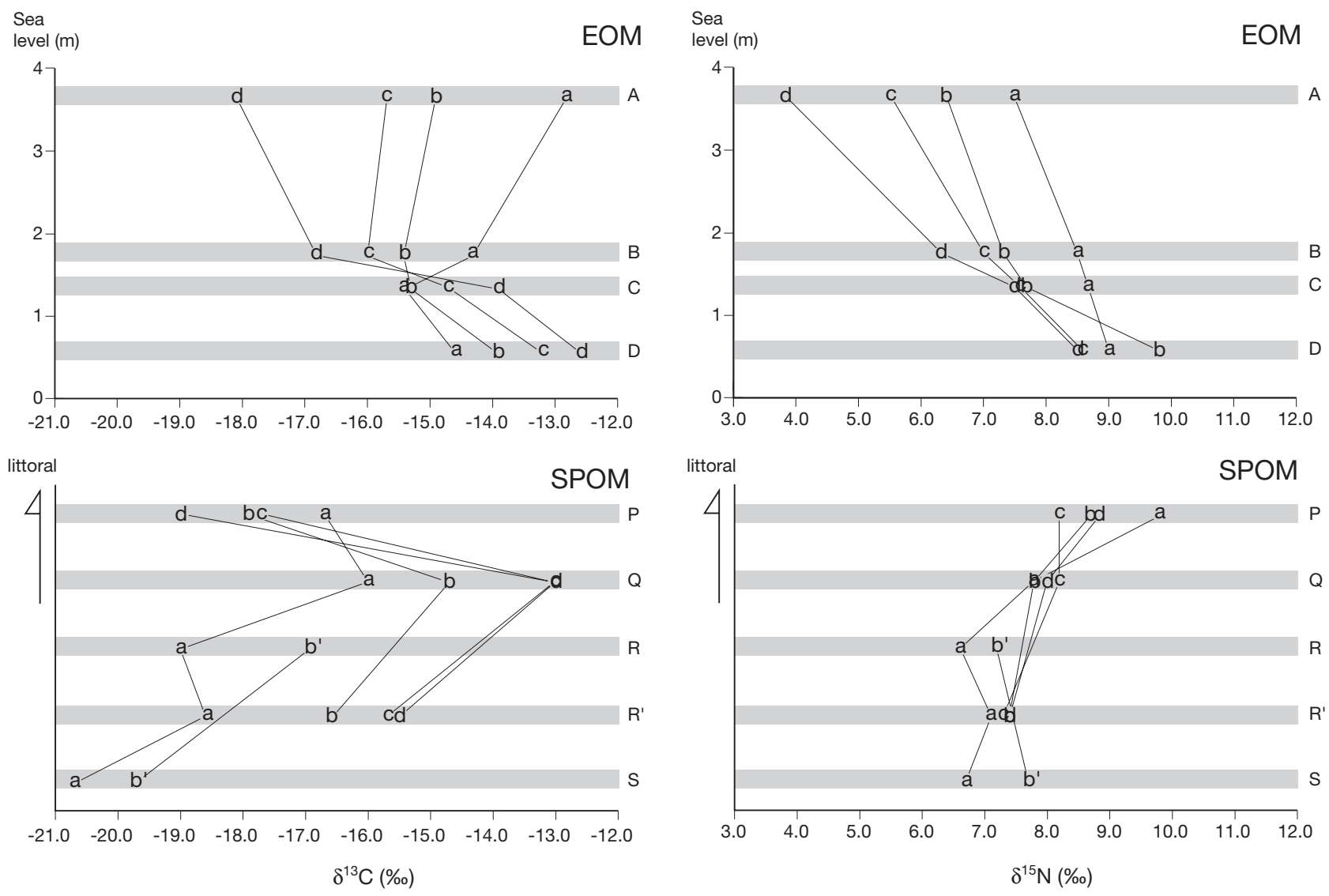

a: $0.7-15 \mu \mathrm{m}$; b: $15-32 \mu \mathrm{m}$; c: 32-63 $\mu \mathrm{m}$; d: 63-125 $\mu \mathrm{m}$; b': 15-125 $\mu \mathrm{m}$

a: 0.7-15 $\mu \mathrm{m}$; b: 15-32 $\mu \mathrm{m}$; c: 32-63 $\mu \mathrm{m}$; d: 63-125 $\mu \mathrm{m}$; b': 15-125 $\mu \mathrm{m}$

Fig. 2. $\delta^{13} \mathrm{C}$ distributions of the epilithic organic matter collected at the 4 sea-level points (A, B, C and D) and the suspended particulate organic matter collected at a tide pool point (P), a shoreline point $(\mathrm{Q})$, a $2 \mathrm{~m}$ depth point (surface, $\mathrm{R}$ ), a $2 \mathrm{~m}$ depth point (bottom, $\mathrm{R}^{\prime}$ ) and an offshore surface point (S). One sample was collected for each combination of sampling points and particle-size fractions

$\left.\chi_{\mathrm{r}}^{2}=6.5, a=3, b=4, \mathrm{p}<0.05\right)$. A significant difference was also found for $\delta^{15} \mathrm{~N}$ among the 3 points $(\mathrm{P}, \mathrm{Q}$ and $\mathrm{R}^{\prime}$ ) (Friedman's test, $\chi_{\mathrm{r}}^{2}=7.6, a=3, b=4, \mathrm{p}<0.05$ ). On the other hand, significant particle size-related differences were not found for either $\delta^{13} \mathrm{C}$ or $\delta^{15} \mathrm{~N}$ of the SPOM (Friedman's test; $\delta^{13} \mathrm{C}, \chi_{\mathrm{r}}^{2}=2.0, a=4, b=3$; $\delta^{15} \mathrm{~N}, \chi_{\mathrm{r}}^{2}=1.2, a=4, b=3$ ).

\section{Species compositions of microalgae}

Species compositions of the microalgae in the EOM were strikingly different among the sampling points (Table 1). Blue-green algae, Homoeothrix sp. and Pleurocapsales sp., occupied as much as $82.2 \%$ of the microalgae collected at the highest sea-level point (A),

Fig. 3. $\delta^{15} \mathrm{~N}$ distributions of the epilithic organic matter collected at the 4 sea-level points (A, B, C and D) and the suspended particulate organic matter collected at a tide pool point $(\mathrm{P})$, a shoreline point $(\mathrm{Q})$, a $2 \mathrm{~m}$ depth point (surface, $\mathrm{R}$ ), a $2 \mathrm{~m}$ depth point (bottom, $\mathrm{R}^{\prime}$ ) and an offshore surface point (S). One sample was collected for each combination of sampling points and particle-size fractions

while species diversity and percentage of diatom species obviously increased at the lower points (C and D). The diatom group consisted mainly of the genera Nitzschia, Cocconeis, Amphora, Navicula, Gomphonema, Grammatophora, Achnanthes and Thalassiosira. Nitzschia sp. 1, which was the most abundant species at Pts. B and C, was a small-sized species closely resembling Nitzschia frustlum.

Species compositions of the microalgae in the SPOM also showed striking local variation (Table 1). Only 3 species, Plagioselmis sp., Kephyrion spirale and Pyramimonas sp., occupied $86.6 \%$ of the suspended microalgae collected at the tide pool point (P) and only 2 species, Chaetoceros sociale and Plagioselmis sp., occupied $90.7 \%$ at the offshore surface point (S). By contrast, the microalgae collected from the shoreline 
point $(\mathrm{Q})$ and the bottom of the $2 \mathrm{~m}$ depth point ( $\mathrm{R}^{\prime}$ ) included a large number of diatom species. The microalgae at Pt. Q consisted mainly of the diatoms Thalassiosira, Cocconeis, Chaetoceros, Skeletonema, Achnanthes, Gomphonema, Amphora, Nitzschia and Berkeleya.

The microalgae in the epilithic matter collected at Pts. B, C and D were abundantly found in the turbid water collected in the surf zone (Pts. Q and R') (Table 1). Particularly, 41.1\% (12 species) of the suspended microalgae collected at the shoreline point (Q) were the same species as the microalgae collected from the epilithic matter. The water at Pt. Q also included Thalassiosira spp. (24.6\%), Amphora spp. (5.1\%), Nitzschia spp. (5.0\%), Cocconeis spp. (2.9\%), Navicula spp. (2.2\%) and Diploneis spp. $(0.9 \%)$, which were found in the epilithic matter. On the other hand, Plagioselmis sp., Kephyrion spirale, Pyramimonas sp. and Chaetoceros sociale, predominant in the calm water collected at the tide pool point $(\mathrm{P})$ and at the offshore surface point (S), were scarcely found in the epilithic matter.

\section{Stable isotope ratios of benthic invertebrates}

The stable isotope ratios of the molluscs collected on 22 February 2000 markedly varied according to species in both $\delta^{13} \mathrm{C}$ and $\delta^{15} \mathrm{~N}$ (Table 2). There were significant differences among chitons Liolophura japonica, limpets Cellana nigrolineata, warty murex Reishia clavigera, centipede shells Serpulorbis imbricatus, ark shells Barbatia virescens, and Japanese oysters Crassostrea gigas (Kruskal-Wallis test; $\delta^{13} \mathrm{C}$, $H=58.3$, df $=5, \mathrm{p}<0.001 ; \delta^{15} \mathrm{~N}, H=$ 54.3, df $=5, \mathrm{p}<0.001)$. Herbivorous species, e.g. L. japonica, limpet Cellana toreuma, C. nigrolineata, lipped periwinkle Monodonta labio, and Lunella coronata coreensis (turban shell), showed wide $\delta^{13} \mathrm{C}$ variation, ranging from $-13.7 \pm 0.8 \%$ for $C$. nigrolineata to $-10.2 \%$ for $C$. toreuma, in contrast to the small variation of $\delta^{15} \mathrm{~N}$ (10.6\% for
Table 1. Percentage compositions of microalgal cells $(<125 \mu \mathrm{m})$ in the epilithic organic matter (EOM) collected at 4 sea-level points (A, B, C and D) and in the suspended particulate organic matter (SPOM) collected at a tide pool point (P), a shoreline point $(\mathrm{Q})$, a $2 \mathrm{~m}$ depth point (surface, $\mathrm{R}$ ), a $2 \mathrm{~m}$ depth point (bottom, $\left.\mathrm{R}^{\prime}\right)$ and an offshore surface point (S) on 22 December 2000. The number of colonies or filaments was counted for blue-green algae

\begin{tabular}{|c|c|c|c|c|c|c|c|c|c|}
\hline \multirow{2}{*}{ Species } & \multicolumn{4}{|c|}{$-\mathrm{EOM}-$} & \multirow[b]{2}{*}{$\mathrm{P}$} & \multirow[b]{2}{*}{ Q } & \multirow{2}{*}{$\begin{array}{c}\text { SPOM } \\
\text { R }\end{array}$} & \multirow[b]{2}{*}{$\mathrm{R}^{\prime}$} & \multirow[b]{2}{*}{$\mathrm{S}$} \\
\hline & A & B & $\mathrm{C}$ & $\mathrm{D}$ & & & & & \\
\hline \multicolumn{10}{|l|}{ DINOPHYCEAE } \\
\hline Prorocentrum dentatum & & & & & & & 0.9 & & \\
\hline Prorocentrum minimum & & & & & & & & & 0.0 \\
\hline Protoperidinium bipes & & & & & 0.6 & & & & \\
\hline \multirow{2}{*}{\multicolumn{10}{|c|}{ CHRYSOPHYCEAE }} \\
\hline & & & & & & & & & \\
\hline Kephyrion spirale & & & & & 31.5 & & 7.8 & 2.8 & 1.0 \\
\hline \multicolumn{10}{|l|}{ Distephanus speculum } \\
\hline var. octonarius & & & & & 0.6 & 0.1 & & & 0.0 \\
\hline Dictyocha fibula & & & & & & 0.1 & & 0.1 & \\
\hline \multicolumn{10}{|l|}{ CRYPTOPHYCEAE } \\
\hline Plagioselmis sp. & & & & & 43.3 & 0.2 & 29.4 & 6.5 & 29.9 \\
\hline \multicolumn{10}{|l|}{ BACILLARIOPHYCEAE } \\
\hline Thalassiosira rotula & & & & & & & 0.2 & & 0.1 \\
\hline Thalassiosira spp. & & 0.2 & 6.9 & 5.4 & 0.6 & 24.6 & 27.7 & 6.3 & 3.8 \\
\hline Corethron hystrix & & & & & & & 0.3 & & 0.0 \\
\hline Melosira nummuloides & & & 0.4 & & 0.6 & & & 0.5 & 0.1 \\
\hline Coscinodiscus spp. & & & & & & 0.3 & 0.5 & 3.6 & \\
\hline Rhizosolenia setigera & & & & & 0.6 & & & 0.1 & \\
\hline Rhizosolenia stolterfothii & & & & & & & 0.5 & & \\
\hline Eucampia zodiacus & & & & & & & 0.2 & & 0.7 \\
\hline Hemiaulus sinensis & & & & & & & & & 0.1 \\
\hline Chaetoceros affine & & & & & & & 0.5 & 1.4 & 0.1 \\
\hline Chaetoceros curvisetum & & & & & & & 0.5 & & \\
\hline Chaetoceros debile & & & & & & & 0.7 & 2.5 & 0.2 \\
\hline Chaetoceros didymum & & & & & & 0.2 & & & \\
\hline Chaetoceros sociale & & & & & & 1.5 & 5.9 & 15.5 & 60.8 \\
\hline Chaetoceros spp. & & & & & & 7.6 & & 12.0 & \\
\hline Ditylum brightwellii & & & & & & & 0.7 & 0.2 & 0.1 \\
\hline Grammatophora marina & & & 3.3 & 6.1 & 2.2 & 1.3 & & 1.7 & \\
\hline Achnanthes brevipes & 0.1 & 11.7 & 6.6 & 4.7 & & 3.8 & & 0.5 & \\
\hline Achnanthes longipes & & 2.6 & 2.8 & 3.0 & 0.6 & 5.8 & & 1.1 & \\
\hline Amphora bigibba & & & & 0.2 & & & & & \\
\hline Amphora lineolata & & & & & & & 0.3 & & \\
\hline Amphora ventricosa & & & 1.0 & 6.1 & & & & & \\
\hline Amphora spp. & 0.1 & 0.1 & 6.9 & 10.0 & & 5.1 & & 2.8 & \\
\hline Navicula duerrenbergiana & & & 5.1 & 10.0 & & 0.5 & & 1.4 & \\
\hline Navicula gregaria & & & 0.4 & & & & & & \\
\hline Navicula johanrosii & & & & 0.2 & & & & & \\
\hline Navicula perminuta & & & 1.2 & 4.7 & & 2.9 & & & \\
\hline Navicula platyventris & & & 0.2 & 0.2 & & & & & \\
\hline Navicula ramosissima & & & 5.7 & 3.3 & & & & & \\
\hline Navicula spp. & 0.2 & 0.2 & 5.1 & 3.4 & 0.6 & 2.2 & 0.2 & 2.8 & 0.1 \\
\hline Pleurosigma spp. & & & & & 1.1 & 0.2 & & & 0.1 \\
\hline Nitzschia coarctata & & & 1.6 & 0.3 & & 0.5 & & 0.2 & \\
\hline Nitzschia longissima & & & & & 0.6 & & 0.3 & & 0.0 \\
\hline Nitzschia pungens & & & & & & & 0.3 & & 0.0 \\
\hline Nitzschia valdestriata & & & 2.3 & & & & & & \\
\hline Nitzschia vidovichii & & & 0.4 & & & & & & \\
\hline Nitzschia sp.1 & 9.4 & 49.9 & 10.0 & 4.0 & & 4.3 & & & \\
\hline Nitzschia spp. & 0.1 & 0.3 & 9.0 & 8.1 & 2.2 & 5.0 & 0.5 & 4.6 & 0.1 \\
\hline Berkeleya rutilans & & & 1.9 & 1.0 & & 3.6 & & & \\
\hline Biddulphia sp. & & & & & & & & 1.7 & \\
\hline Cocconeis pseudomarginato & & 0.1 & 1.4 & 10.0 & & 1.1 & & 3.6 & \\
\hline Cocconeis scutellum & & 0.4 & 4.8 & 7.4 & & 11.4 & & 5.6 & \\
\hline Cocconeis spp. & & & 5.7 & & & 2.9 & & 4.9 & \\
\hline Diploneis spp. & & & 0.6 & 0.3 & & 0.9 & & 0.5 & \\
\hline Gomphonema exiguum & & & & & & & & & \\
\hline var. minutissimum & & & 8.1 & 5.4 & & 5.8 & & 1.1 & \\
\hline Odontella sinensis & & & & & & 0.2 & & 0.3 & \\
\hline Paralia sulcata & & & & & & 1.1 & & 3.6 & \\
\hline Skeletonema costatum & & & & & & 6.5 & & 1.9 & \\
\hline
\end{tabular}


Table 1 (continued)

\begin{tabular}{|c|c|c|c|c|c|c|c|c|c|}
\hline \multirow{2}{*}{ Species } & \multicolumn{4}{|c|}{$-\mathrm{EOM}-$} & \multirow[b]{2}{*}{$\mathrm{P}$} & \multirow[b]{2}{*}{$\mathrm{Q}$} & \multicolumn{2}{|c|}{ SPOM- } & \multirow[b]{2}{*}{$\mathrm{S}$} \\
\hline & A & B & $\mathrm{C}$ & $\mathrm{D}$ & & & $\mathrm{R}$ & $\mathrm{R}^{\prime}$ & \\
\hline Stephanopyxis palmeriana & & & & & & & & 0.4 & \\
\hline Synedra tabulata & & & 3.3 & 1.7 & & & & 0.5 & \\
\hline Trachyneis aspera & & & & & & & & 0.8 & \\
\hline Licmophora abbreviata & & & 0.6 & 1.0 & & & & & \\
\hline Mastogloia sp. & & & & 0.2 & & & & & \\
\hline Stauroneis smithii & & & & 0.6 & & & & & \\
\hline Surirella sp. & & & 0.2 & & & & & & \\
\hline Bacillariophyceae spp. & & & 1.9 & 0.6 & & & & & \\
\hline PRASINOPHYCEAE & & & & & & & & & \\
\hline Pyramimonas aff. amyliferc & & & & & & 0.1 & & & \\
\hline $\begin{array}{l}\text { Pyramimonas sp. } \\
\text { EUGLENOPHYCEAE }\end{array}$ & & & & & 11.8 & & 22.5 & 8.5 & 2.4 \\
\hline $\begin{array}{l}\text { Eutreptiella sp. } \\
\text { CYANOPHYCEAE }\end{array}$ & & & & & 0.6 & 0.1 & & & 0.1 \\
\hline Oscillatoria sp. & & 2.9 & 0.1 & 0.1 & 2.8 & 0.1 & & & \\
\hline Calothrix sp. & 0.1 & 0.2 & & 0.1 & & & & & \\
\hline Chamaesiphon sp. & 5.8 & 0.1 & 0.2 & & & & & & \\
\hline Homoeothrix sp. & 60.8 & 17.0 & & 0.4 & & & & & \\
\hline Chroococcaceae sp. & 2.0 & & & & & & & & \\
\hline Stigonemataceae sp. & & 2.0 & & 0.3 & & & & & \\
\hline $\begin{array}{l}\text { Pleurocapsales sp. } \\
\text { CHLOROPHYCEAE }\end{array}$ & 21.4 & 12.3 & 2.2 & 1.2 & & & & & \\
\hline Chlorophyceae sp. & & & 0.1 & & & & & & \\
\hline
\end{tabular}

$14.1 \%$, respectively. These carnivorous gastropods had clearly higher $\delta^{15} \mathrm{~N}$ than the herbivores and suspension feeders.

The small benthic crustaceans, both amphipods and decapods, collected on 22 December 2000 had $\delta^{13} \mathrm{C}$ distributed in a narrow range of -15.0 to $-12.8 \%$ o (Table 3). The barnacles Pollicipes mitella collected on 22 February 2000 also showed a similar $\delta^{13} \mathrm{C}$ value of $-15.4 \%$. On the other hand, these crustaceans had a $\delta^{15} \mathrm{~N}$ differing according to species; the $\delta^{15} \mathrm{~N}$ value determined for multiple individuals was 4.3 to $9.1 \%$ for amphipods, 11.4 to $11.7 \%$ for decapods and $14.7 \%$ for barnacles. The distribution of the amphipods on the $\delta^{13} \mathrm{C}-\delta^{15} \mathrm{~N}$ map was similar to that of Serpulorbis imbricatus, while the distribution of the decapods was similar to the distributions of the gastropods Cellana nigrolineata and Monodonta labio and the bivalves Barbatia virescens,

C. toreuma to $11.2 \%$ for M. labio) (Fig. 4). On the other hand, suspension-feeding species, e.g. S. imbricatus, B. virescens, C. gigas and variegated cardita Cardita variegata, showed wide $\delta^{15} \mathrm{~N}$ variation, ranging from $7.8 \pm 0.6 \%$ or $S$. imbricatus to $12.0 \%$ o for C. variegata, in contrast to the small variation in $\delta^{13} \mathrm{C}$ (from $-15.2 \pm$ $0.2 \%$ for C. gigas and $-15.2 \%$ for $C$. variegata to -14.9 $\pm 0.2 \%$ for $S$. imbricatus). The $\delta^{13} \mathrm{C}$ and $\delta^{15} \mathrm{~N}$ of the carnivorous species $R$. clavigera and Reishia bronni (murex shell) were distributed in the relatively narrow ranges of $-13.8 \%$ o to $-13.7 \pm 0.5 \%$ ond $13.5 \pm 0.6 \%$ o to
Crassostrea gigas and Cardita variegata (Figs. 4 \& 5). The barnacles overlapped with the fish on the map. The isotopic values of the macroalga Sargassum horneri, to which the small crustaceans in the sublittoral zone attached, were $-17.4 \%$ for $\delta^{13} \mathrm{C}$ and $5.3 \%$ for $\delta^{15} \mathrm{~N}$.

Takai et al. (2002) reported the stable isotope distributions for the small benthic crustaceans that were collected at this shore site; amphipods were collected from 10 August 1999 to 12 October 2000 and decapods were collected on 30 June 2000 and 30 August

Table 2. Number of individuals analyzed (n), shell length (mm) and carbon and nitrogen stable isotope ratios (\%o) for molluscs collected at the shore site of Koguro-Kamijima Island on 22 February 2000. Isotope ratios of Monodonta labio and Lunella coronata coreensis were analyzed for mixed individuals. Number of individuals mixed is shown in parentheses for these species (feeding modes: HE, herbivorous; CA, carnivorous; SU, suspension feeding)

\begin{tabular}{|c|c|c|c|c|c|}
\hline Species & $\mathrm{n}$ & Shell length & $\delta^{13} \mathrm{C}$ & $\delta^{15} \mathrm{~N}$ & Feeding mode \\
\hline \multicolumn{6}{|l|}{ Polyplacophora } \\
\hline Chiton Liolophura japonica & 15 & $32-58$ & $-10.8 \pm 0.6$ & $10.7 \pm 0.4$ & $\mathrm{HE}$ \\
\hline \multicolumn{6}{|l|}{ Gastropoda } \\
\hline Limpet Cellana toreuma & 1 & 36 & -10.2 & 10.6 & $\mathrm{HE}$ \\
\hline Limpet Cellana nigrolineata & 11 & $44-59$ & $-13.7 \pm 0.8$ & $10.9 \pm 0.6$ & $\mathrm{HE}$ \\
\hline Lipped periwinkle Monodonta labio & $1(7)$ & $14-21$ & -13.5 & 11.2 & $\mathrm{HE}$ \\
\hline Turban shell Lunella coronata coreensis & $1(10)$ & $21-24$ & -11.6 & 10.7 & $\mathrm{HE}$ \\
\hline Warty murex Reishia clavigera & 15 & $21-33$ & $-13.7 \pm 0.5$ & $13.5 \pm 0.6$ & $\mathrm{CA}$ \\
\hline Murex shell Reishia bronni & 1 & 45 & -13.8 & 14.1 & CA \\
\hline Centipede shell Serpulorbis imbricatus & 12 & $30-67$ & $-14.9 \pm 0.2$ & $7.8 \pm 0.6$ & SU \\
\hline \multicolumn{6}{|l|}{ Bivalvia } \\
\hline Ark shell Barbatia virescens & 4 & $31-38$ & $-15.1 \pm 0.2$ & $11.0 \pm 0.4$ & SU \\
\hline Japanese oyster Crassostrea gigas & 13 & $33-54$ & $-15.2 \pm 0.2$ & $11.1 \pm 0.3$ & SU \\
\hline Variegated cardita Cardita variegata & 1 & 30 & -15.2 & 12.0 & SU \\
\hline
\end{tabular}




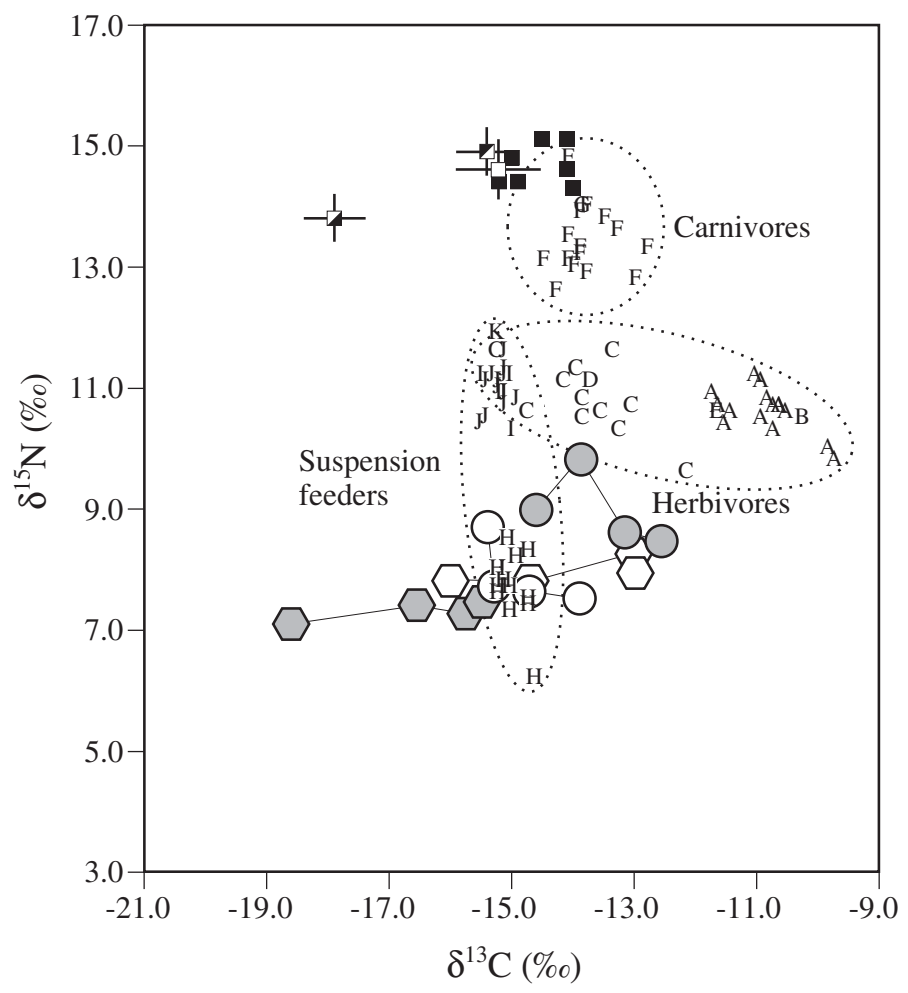

$\begin{array}{ll}\text { A } & \text { Liolophura japonica } \\ \text { B } & \text { Cellana toreuma } \\ \text { C } & \text { Cellana nigrolineata } \\ \text { D } & \text { Monodonta labio } \\ \text { E } & \text { Lunella coronata coreensis } \\ \text { F } & \text { Reishia clavigera } \\ \text { G } & \text { Reishia bronni } \\ \text { H } & \text { Serpulorbis imbricatus } \\ \text { I } & \text { Barbatia virescens } \\ \text { J } & \text { Crassostrea gigas } \\ \text { K } & \text { Cardita variegata }\end{array}$

Fig. 4. $\delta^{13} \mathrm{C}-\delta^{15} \mathrm{~N}$ map for molluscs at the shore site of KoguroKamijima Island. Isotopic distributions of the epilithic organic matter collected at Pts. C and D, the suspended particulate organic matter collected at Pts. Q and R' and the fish collected at this shore site are shown besides the molluscan distribution. Reference data reported by Takai et al. (2002) are also shown for fish as mean values $( \pm \mathrm{SD})$. See 'Results' for information about these organisms

2000 (Fig. 5). For amphipods, $\delta^{13} \mathrm{C}$ ranged from -17.3 to $-12.5 \%$ and $\delta^{15} \mathrm{~N}$ ranged from 6.7 to $9.8 \%$, and, for small decapods, $\delta^{13} \mathrm{C}$ ranged from -16.9 to $-15.7 \%$ and $\delta^{15} \mathrm{~N}$ from 11.4 to $11.8 \%$. Thus, the isotopic distributions of the small benthic crustaceans showed only small seasonal variations, justifying the use of data from 2 different months, December and February, for these comparisons.

\section{Stable isotope ratios of fish}

The fish collected on 22 December 2000 had a $\delta^{13} \mathrm{C}$ ranging from -15.2 to $-14.0 \%$ and a $\delta^{15} \mathrm{~N}$ from 14.3 to $15.1 \%$ (Table 4 ). The $\delta^{13} \mathrm{C}$ values of these 7 fish samples were very similar to those of all the suspension-feeding molluscs and the small benthic crustaceans (Figs. 4 \& 5). They also overlapped in $\delta^{13} \mathrm{C}$ with the herbivorous gastropods Cellana nigrolineata and Monodonta labio, while the high $\delta^{13} \mathrm{C}$ of the other herbivorous species, $\mathrm{Li}$ olophura japonica, C. toreuma, and Lunella coronata coreensis, were far from the $\delta^{13} \mathrm{C}$ distribution of the fish. On the other hand, the fishes had clearly higher $\delta^{15} \mathrm{~N}$ than the invertebrates, except for the barnacles $(14.7 \%$ o).

Takai et al. (2002) reported the stable isotope distributions of the fishes that were collected at this shore site from 15 June 1999 to 30 June 2000 (Figs. 4 \& 5). These fishes had $\delta^{13} \mathrm{C}$ values mainly distributed from -17.0 to $-13.0 \%$ and $\delta^{15} \mathrm{~N}$ values from 14.0 to $16.0 \%$, except for the peculiarly low $\delta^{13} \mathrm{C}$ values $(-18.6$ to $-17.0 \%$ o of juveniles of the black rockfish Sebastes inermis collected in June. Thus, like the small benthic crustaceans, the isotope ratios of the fish did not vary much among different seasons.

\section{DISCUSSION}

\section{Resuspension of the microphytobenthos in the surf zone}

The horizontal distance between the tide pool point (P) and the shoreline point (Q) was only about $3 \mathrm{~m}$, but the stable isotope distribution of the SPOM was different between these points (Figs. $2 \& 3$ ). The $\delta^{13} \mathrm{C}$ distribution of the SPOM at the tide pool point (P) was closer to the distribution of the SPOM at the offshore surface point (S), while the SPOM collected at the shoreline point (Q) and the $2 \mathrm{~m}$ depth point (bottom, R') overlapped in $\delta^{13} \mathrm{C}$ with the EOM collected at the lower sea-level points (B, C and D). This result suggests that the ${ }^{13} \mathrm{C}$-enriched SPOM in the surf zone originated from the ${ }^{13} \mathrm{C}$-enriched EOM on the hard bottom.

The species compositions of the microalgae support this inference based on stable isotope abundance (Table 1). The microalgal species included in the epilithic matter were abundantly found in the suspended matter collected at the shoreline point (Q) and the $2 \mathrm{~m}$ depth point (bottom, R'). By contrast, those algal species found in the epilithic matter were hardly present in the suspended matter collected at the tide pool point $(\mathrm{P})$. It was thus inferred that the organic matter produced by the microphytobenthos increased the $\delta^{13} \mathrm{C}$ values of the SPOM in the surf zone through its resuspension. 
Table 3. Number of individuals mixed for analyses (n), body length (mm), and carbon and nitrogen stable isotope ratios (\%) for crustaceans collected at the shore site of Koguro-Kamijima Island. Each sample consisted of multiple individuals. Amphipods and decapods were collected on 22 December 2000 and barnacles Pollicipes mitella were collected on 22 February 2000 . Epiphytic crustaceans in the sublittoral zone inhabited the leaves of Sargassum macroalgae. Body weight (wet; g) is shown for P. mitella

\begin{tabular}{|c|c|c|c|c|c|}
\hline Species & Zone & $\mathrm{n}$ & Body length & $\delta^{13} \mathrm{C}$ & $\delta^{15} \mathrm{~N}$ \\
\hline \multicolumn{6}{|l|}{ Amphipoda } \\
\hline \multicolumn{6}{|l|}{ Gammaridea } \\
\hline Hyale punctata & Littoral & 10 & $5.3-7.3$ & -12.8 & 9.1 \\
\hline Hyale sp. 1 & Sublittoral & 12 & $3.5-5.6$ & -14.8 & 8.3 \\
\hline Hyale sp. 2 & Littoral & 10 & $6.0-8.8$ & -13.0 & 8.4 \\
\hline Pontogeneia rostrata & Sublittoral & 20 & $3.8-5.5$ & -13.9 & 7.3 \\
\hline Ampithoe sp. & Sublittoral & 6 & $4.6-7.2$ & -13.6 & 4.3 \\
\hline \multicolumn{6}{|l|}{ Caprellidea } \\
\hline Caprella decipiens & Sublittoral & 10 & $9.9-19.0$ & -14.3 & 7.6 \\
\hline Caprella subinermis & Sublittoral & 10 & $9.3-15.5$ & -15.0 & 8.0 \\
\hline \multicolumn{6}{|l|}{ Decapoda } \\
\hline Eualus leptognathus & Sublittoral & 2 & $13.4-18.1$ & -14.1 & 11.4 \\
\hline Hippolyte ventricosa & Sublittoral & 3 & $10.3-12.3$ & -14.9 & 11.7 \\
\hline \multicolumn{6}{|l|}{ Cirripedia } \\
\hline Pollicipes mitella & Littoral & 19 & $-(3.6-8.9 \mathrm{~g})$ & -15.4 & 14.7 \\
\hline
\end{tabular}

Table 4. Standard length ( $\mathrm{mm})$ and carbon and nitrogen stable isotope ratios (\%) for fish collected at the shore site of Koguro-Kamijima Island on 22 December 2000

\begin{tabular}{|lccc|}
\hline Species & $\begin{array}{c}\text { Standard } \\
\text { length }\end{array}$ & $\delta^{13} \mathrm{C}$ & $\delta^{15} \mathrm{~N}$ \\
\hline Surf fish Ditrema temmincki & 98 & -14.9 & 14.4 \\
Hairychin goby Sagamia genetonema & 81 & -14.0 & 14.3 \\
Spottybelly greenling Hexagrammos agrammus & 101 & -15.0 & 14.8 \\
Tiny stinger Hypodytes rubripinnis & 75 & -15.2 & 14.4 \\
& 63 & -14.5 & 15.1 \\
& 61 & -14.1 & 14.6 \\
& 60 & -14.1 & 15.1 \\
\hline
\end{tabular}

likely that such diverse components of the microalgal films led partly to the varied $\delta^{13} \mathrm{C}$ values of the EOM and consequently those of the herbivorous molluscs.

The herbivorous molluscs had $\delta^{15} \mathrm{~N}$ distributed in a narrow range, from 9.7 to $11.7 \%$ (Fig. 4). Compared with the $\delta^{15} \mathrm{~N}$ values of 7.5 to $8.7 \%$ for the EOM collected in the midlittoral zone of the shore (Pt. C), the average $\delta^{15} \mathrm{~N}$ of the herbivores was 2.0 to $3.2 \%$ higher for Liolophura japonica $(10.7 \pm 0.4 \%$ o $), 1.9$ to $3.1 \%$ higher for Cellana toreuma

\section{Carbon transfer from microphytobenthos to herbivorous molluscs}

The $\delta^{13} \mathrm{C}$ of herbivorous molluscs, which scrape off epilithic matter with radulae, varied, reflecting the wide $\delta^{13} \mathrm{C}$ variations of the EOM (Fig. 4). Although the high $\delta^{13} \mathrm{C}$ in Liolophura japonica and Cellana toreuma appeared to be distributed somewhat far away from the $\delta^{13} \mathrm{C}$ of the EOM, this $\delta^{13} \mathrm{C}$ difference may be caused by the difference of the sampling dates and/or the slight positional difference between the sampling points of the EOM and the molluscs; the $\delta^{13} \mathrm{C}$ of the EOM might be higher at the site where these ${ }^{13} \mathrm{C}$-enriched molluscs were collected. These herbivorous molluscs are generally supposed to feed on the microalgae attached to the hard bottom (Tsuchiya 1988), while the microalgal films on hard surfaces consist of not only microalgae, but also organic molecules, heterotrophic bacteria, fungi, protistans and the early stages of macroalgae (Raffaelli \& Hawkins 1999). It is
(10.6\%), 2.2 to $3.4 \%$ higher for C. nigrolineata $(10.9 \pm$ $0.6 \%$ ) , 2.5 to $3.7 \%$ higher for Monodonta labio (11.2\%o) and 2.0 to $3.2 \%$ higher for Lunella coronata coreensis $\left(10.7 \%\right.$ ). This $\delta^{15} \mathrm{~N}$ difference of 1.9 to $3.7 \%$ between the herbivores and the EOM corresponds to the difference of 0.56 to 1.1 in trophic level, calculated on the basis of $3.4 \%$ increase per trophic level (Minagawa \& Wada 1984, Vander Zanden et al. 1997). It is likely that the $\delta^{15} \mathrm{~N}$ signatures were a very close reflection of the simple feeding relationship between the herbivorous molluscs and the epilithic microalgae.

\section{Carbon transfer from microphytobenthos to suspension-feeding molluscs and small benthic crustaceans}

The isotopic signatures of suspension-feeding molluscs, Barbatia virescens, Crassostrea gigas and Cardita variegata, were similar to those of the herbivorous 

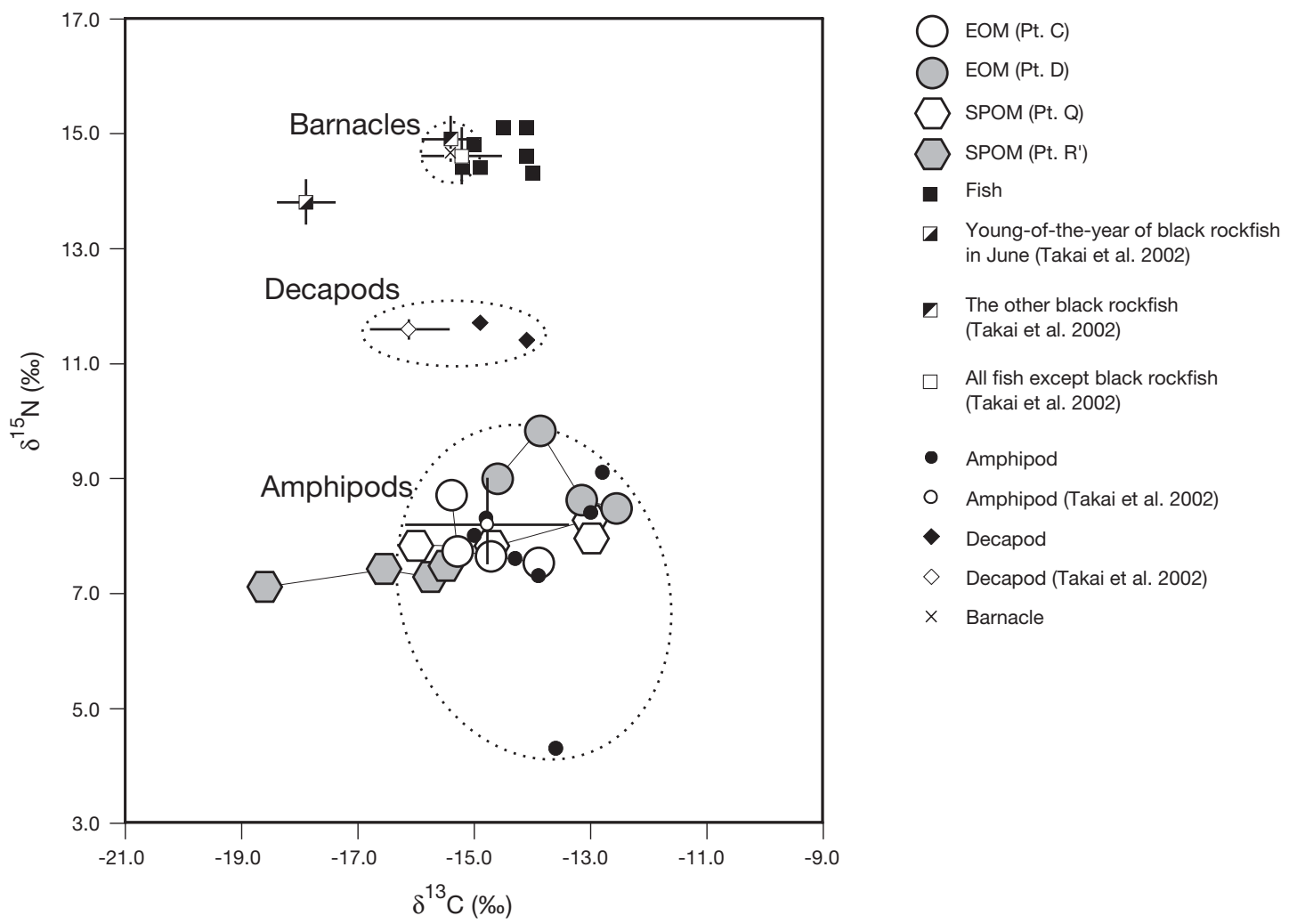

Fig. 5. $\delta^{13} \mathrm{C}-\delta^{15} \mathrm{~N}$ map for crustaceans at the shore site of Koguro-Kamijima Island. Isotopic distributions of the epilithic organic matter collected at Pts. C and D, the suspended particulate organic matter collected at Pts. Q and R' and the fish collected at this shore site are shown besides the crustacean distribution. Reference data reported by Takai et al. (2002) are also shown for fish and crustaceans as mean values $( \pm \mathrm{SD})$. See 'Results' for information about these organisms

gastropods Cellana nigrolineata and Monodonta labio (Fig. 4). Such isotope distributions indicate that these suspension feeders depended on microphytobenthosoriginating organic matter as well as herbivorous gastropods for food sources in spite of the difference in their feeding styles. They probably feed on ${ }^{13} \mathrm{C}$-enriched organic matter resuspended in the surf zone.

The small epiphytic decapods Eualus leptognathus and Hippolyte ventricosa, collected from the Sargassum macroalgae which consisted mainly of $S$. horneri, showed similar isotopic signatures (Fig. 5). We considered that these decapods were also supported by the resuspended organic matter of microphytobenthos origin. The stable isotope ratios of this macroalga (S. horneri) were $-17.4 \%$ for $\delta^{13} \mathrm{C}$ and $5.3 \%$ for $\delta^{15} \mathrm{~N}$, being 2.5 to $3.3 \%$ more depleted in $\delta^{13} \mathrm{C}$ and 6.1 to $6.4 \%$ more depleted in $\delta^{15} \mathrm{~N}$ than small epiphytic decapods. These isotopic differences between the macroalga and decapods were so large that these decapods were unlikely to feed on this macroalga and its detritus. However, Takai et al. (2001) reported that some species of macroalgae showed higher isotopic values in both $\delta^{13} \mathrm{C}$ and $\delta^{15} \mathrm{~N}$ at this shore site in winter; the macroalgae ranged from -30.3 to $-13.9 \%$ for $\delta^{13} \mathrm{C}$ and from 7.4 to $11.3 \%$ for $\delta^{15} \mathrm{~N}$ on 22 February 2000 . Accordingly, it is necessary to pay attention to the potential carbon supply from macroalga-originating organic matter as a form of small-sized detritus.

The centipede shells Serpulorbis imbricatus showed the strikingly depleted $\delta^{15} \mathrm{~N}$ value of 6.3 to $8.6 \%$ among the suspension-feeding molluscs (Fig. 4). This $\delta^{15} \mathrm{~N}$ distribution was similar to the distribution of the amphipods, suggesting that these invertebrates depended on the same kind of food source. We hypothesized that such ${ }^{15} \mathrm{~N}$-depleted invertebrates might partly utilize the organic matter that was produced by blue-green algae through $\mathrm{N}_{2}$ fixation. There has been little isotope fractionation reported for $\mathrm{N}_{2}$ fixation by blue-green algae in a variety of marine and terrestrial ecosystems (Wada \& Hattori 1991). In fact, the $\delta^{15} \mathrm{~N}$ of the EOM at this shore site was clearly depleted at Pt. A, where the blue-green algae were predominant in the EOM (Table 1, Fig. 3). The centipede shells $S$. imbricatus and the amphipods might use such ${ }^{15} \mathrm{~N}$-depleted organic matter produced at the littoral fringe. 


\section{Carbon transport to predators}

The carnivorous gastropods Reishia clavigera and $R$. bronni had $\delta^{13} \mathrm{C}$ values similar to those of the herbivorous gastropod species Cellana nigrolineata and Monodonta labio and those of the bivalve species Barbatia virescens, Crassostrea gigas and Cardita variegata (Fig. 4). The average $\delta^{15} \mathrm{~N}$ of $R$. clavigera $(13.5 \pm$ $0.6 \%$ ) was $2.6 \%$ higher than that of $C$. nigrolineata, $2.3 \%$ higher than that of M. labio, $2.5 \%$ higher than that of $B$. virescens, $2.4 \%$ higher than that of $C$. gigas and $1.5 \%$ higher than that of C. variegata. The $\delta^{15} \mathrm{~N}$ value of $R$. bronni (14.1\%) was 3.2\% higher than that of C. nigrolineata, $2.9 \%$ higher than that of $M$. labio, $3.1 \%$ higher than that of $B$. virescens, $3.0 \%$ higher than that of $C$. gigas and $2.1 \%$ higher than that of C. variegata. Judging from the $3.4 \%$ increase per trophic level (Minagawa \& Wada 1984, Vander Zanden et al. 1997), $R$. clavigera and $R$. bronni had trophic positions estimated to be 0.76 and 0.94 higher than those of $C$. nigrolineata, 0.68 and 0.85 higher than those of M. labio, 0.74 and 0.91 higher than those of B. virescens, 0.71 and 0.88 higher than those of C. gigas and 0.44 and 0.62 higher than those of $C$. variegata. The Reishia species is generally supposed to feed on molluscs inhabiting the littoral zone (Tsuchiya 1988). The Reishia species at this shore site would take in the microphytobenthos-originating organic matter through this prey-predator relationship with lower trophic positional molluscs.

The stable isotope distribution of the 7 fish samples was slightly more depleted in $\delta^{13} \mathrm{C}$ and more enriched in $\delta^{15} \mathrm{~N}$ relative to the carnivorous Reishia gastropods (Fig. 4). Consequently, the $\delta^{13} \mathrm{C}$ values were lower in these fish than in the herbivorous gastropods and close to those in the bivalves and the small benthic decapods. The Reishia gastropods can make a hole in the shell of the limpets with a radula to feed on them, while it would be difficult for the fish to feed on limpets clinging to the hard surface. It was thus inferred that both or either of the bivalves and the small benthic crustaceans were more important as food sources for the fish than the herbivorous gastropods. These 7 fish samples had an average $\delta^{15} \mathrm{~N}$ of $14.7 \pm$ $0.3 \%$, which is 2.7 to $4.3 \%$ higher than that of the bivalves (10.4 to $12.0 \%$ ) and the small benthic decapods (11.4 to $11.7 \%$ o). These differences correspond to a change of 0.79 to 1.3 in trophic level, calculated on the basis of $3.4 \%$ increase per trophic level (Minagawa \& Wada 1984, Vander Zanden et al. 1997). These $\delta^{15} \mathrm{~N}$ signatures support the inference that bivalves and small benthic decapods are important food sources for the fish.

In the present study, all heterotrophs showed clearly higher $\delta^{13} \mathrm{C}$ signatures of -15.5 to $-9.7 \%$ relative to those of -20.7 to $-19.7 \%$ for the SPOM in the offshore surface water. It was suggested that this ${ }^{13} \mathrm{C}$ enrichment was caused by the inflow of microphytobenthosoriginating organic matter into the food web of the exposed hard bottom shore via multiple pathways, such as herbivorous and suspension-feeding molluscs and small benthic crustaceans (Fig. 6). Since the isotope distributions of the fish and the small benthic crustaceans analyzed in the present study were consistent with the year-long isotopic values of these heterotrophs (Takai et al. 2002), it was expected that these transport pathways may function effectively all year round. These transport pathways might also be effective in different exposed shore areas that consist of a hard bottom, but whether or not they apply to 'sheltered' hard bottom shores is unknown. In the future, the relationship between the topographical features of hard bottom shores and the roles of primary consumers in the shore food webs should be investigated in detail.

Acknowledgements. We thank E. Wada for his critical reading of this manuscript. We are grateful to K. Imamura for his cooperation in the identification of the molluscs, and S. Ishida, T. Kurihara and S. Handa, for their useful advice in the preparation of this manuscript. We are also grateful to 3 anonymous reviewers for their valuable comments on the manuscript.

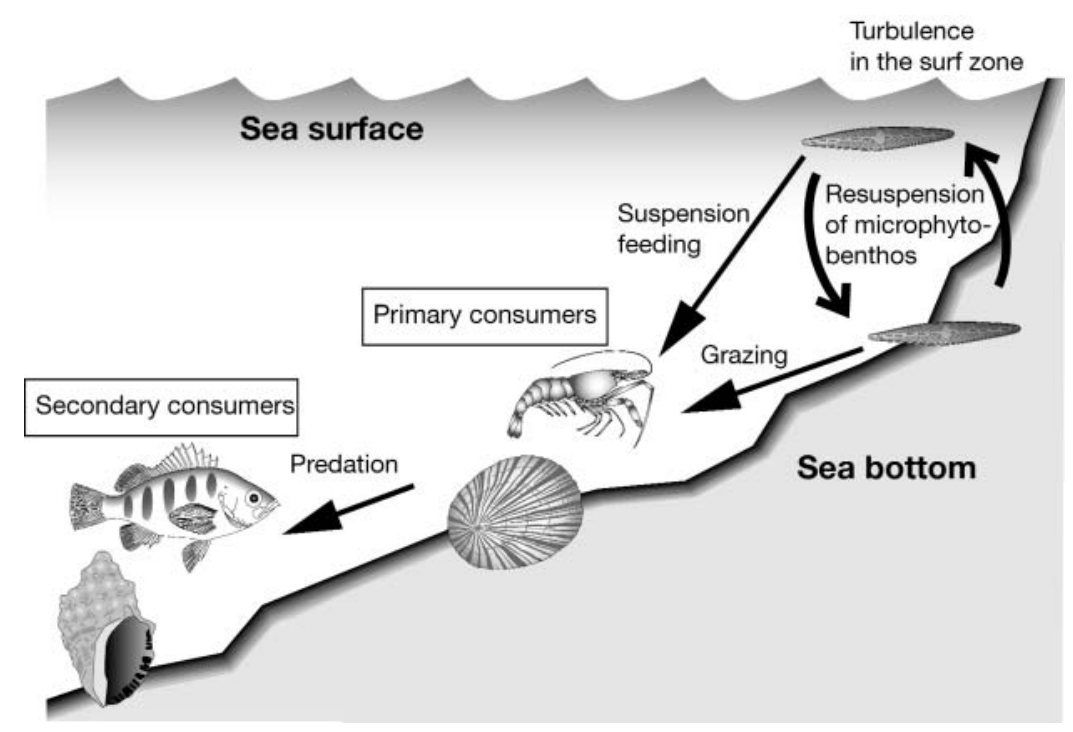

Fig. 6. Schematic diagram of the carbon transport from microphytobenthos to predators in the food web of the exposed hard bottom shore at Koguro-Kamijima Island 
This study was supported by a grant from Japan Science and Technology Corporation and Open Research Center Project of Nihon University promoted by the Ministry of Education, Culture, Sports, Science and Technology of Japan.

\section{LITERATURE CITED}

Anonymous (1994) The report of the marine biotic environment survey in the 4 th national survey on the natural environment, Vol 2. Algal and sea-grass beds. Marine Parks Center of Japan, Tokyo (in Japanese)

de Jonge VN, van Beusekom JEE (1992) Contribution of resuspended microphytobenthos to total phytoplankton in the Ems estuary and its possible role for grazers. Neth J Sea Res 30:91-105

DeNiro MJ, Epstein S (1978) Influence of diet on the distribution of carbon isotopes in animals. Geochim Cosmochim Acta 42:495-506

DeNiro MJ, Epstein S (1981) Influence of diet on the distribution of nitrogen isotopes in animals. Geochim Cosmochim Acta 45:341-351

France RL (1995) Carbon-13 enrichment in benthic compared to planktonic algae: foodweb implications. Mar Ecol Prog Ser 124:307-312

Fry B (1988) Food web structure on Georges Bank from stable C, N, and S isotopic compositions. Limnol Oceanogr 33: $1182-1190$

Fry B, Sherr EB (1984) $\delta^{13} \mathrm{C}$ measurements as indicators of carbon flow in marine and freshwater ecosystems. Contrib Mar Sci 27:13-47

Herman PMJ, Middelburg JJ, Widdows J, Lucas CH, Heip CHR (2000) Stable isotopes as trophic tracers: combining field sampling and manipulative labelling of food resources for macrobenthos. Mar Ecol Prog Ser 204:79-92

Ichihara K (1990) Statistics for bioscience-practical technique and theory. Nankodo, Tokyo (in Japanese)

Kamermans P (1994) Similarity in food source and timing of feeding in deposit- and suspension-feeding bivalves. Mar Ecol Prog Ser 104:63-75

MacIntyre HL, Geider RJ, Miller DC (1996) Microphytobenthos: the ecological role of the 'secret garden' of unvegetated, shallow-water marine habitats. I. Distribution, abundance and primary production. Estuaries 19: 186-201

Middelburg JJ, Barranguet C, Boschker HTS, Herman PMJ, Moens T, Heip CHR (2000) The fate of intertidal microphytobenthos carbon: an in situ ${ }^{13} \mathrm{C}$-labeling study. Limnol Oceanogr 45:1224-1234

Editorial responsibility: Otto Kinne (Editor), Oldendorf/Luhe, Germany
Minagawa M, Wada E (1984) Stepwise enrichment of ${ }^{15} \mathrm{~N}$ along food chains: further evidence and the relation between $\delta^{15} \mathrm{~N}$ and animal age. Geochim Cosmochim Acta 48:1135-1140

Ono K, Yamamoto T, Hashimoto T (1999) Importance of benthic algal production in Hiroshima Bay. The abstract of the JOS fall meeting in 1999. The Oceanographic Society of Japan, Tokyo, p 249 (in Japanese)

Raffaelli D, Hawkins S (1999) Intertidal ecology, 2nd edn. Kluwer Academic Publishers, Dordrecht

Rau GH, Mearns AJ, Young DR, Olson RJ, Schafer HA, Kaplan IR (1983) Animal ${ }^{13} \mathrm{C} /{ }^{12} \mathrm{C}$ correlates with trophic level in pelagic food webs. Ecology 64:1314-1318

Tada K, Monaka K, Morishita M, Hashimoto T (1998) Standing stocks and production rates of phytoplankton and abundance of bacteria in the Seto Inland Sea, Japan. J Oceanogr 54:285-295

Takai N, Hoshika A, Imamura K, Yorozu A, Tanimoto T, Mishima Y (2001) Distribution of carbon and nitrogen stable isotope ratios in macroalgae in Hiroshima Bay. Jpn J Ecol 51:177-191 (in Japanese with English abstract)

Takai N, Mishima Y, Yorozu A, Hoshika A (2002) Carbon sources for demersal fish in the western Seto Inland Sea, Japan, examined by $\delta^{13} \mathrm{C}$ and $\delta^{15} \mathrm{~N}$ analyses. Limnol Oceanogr 47:730-741

Tsuchiya M (1988) II. Ecology and environment. 1. Food relationship and environmental characteristics. 11. Life style and environment. In: Kurihara Y (ed) Ecology and ecotechnology in estuarine-coastal areas. Tokai University Press, Tokyo, p 43-54 (in Japanese)

Underwood GJC, Kromkamp J (1999) Primary production by phytoplankton and microphytobenthos in estuaries. Adv Ecol Res 29:93-153

Van der Zanden MJ, Cabana G, Rasmussen JB (1997) Comparing trophic position of freshwater fish calculated using stable nitrogen isotope ratios $\left(\delta^{15} \mathrm{~N}\right)$ and literature dietary data. Can J Fish Aquat Sci 54:1142-1158

Wada E, Hattori A (1991) Nitrogen in the sea: forms, abundances, and rate processes. CRC Press, Boca Raton, FL

Wada E, Terazaki M, Kabaya Y, Nemoto T (1987) ${ }^{15} \mathrm{~N}$ and ${ }^{13} \mathrm{C}$ abundances in the Antarctic Ocean with emphasis on the biogeochemical structure of the food web. Deep-Sea Res 34:829-841

Yorozu A (2000) Environmental characteristics of shores in Hiroshima Bay inferred from carbon and nitrogen stable isotope ratios of shellfish. MSc thesis, Hiroshima University, Higashi-Hiroshima, (in Japanese)

Zar JH (1996) Biostatistical analysis, 3rd edn. Prentice-Hall International, London

Submitted: November 20, 2003; Accepted: July 29, 2004

Proofs received from author(s): December 9, 2004 